\title{
The Representation of Character Education in the Characterizations of Lily Owens in Sue Monk Kidd's The Secret Life of Bees
}

\author{
I Gusti Ayu Diah Gita Saraswati ${ }^{1}$ Ni Komang Arie Suwastini ${ }^{1, *}$ Ida Ayu Made Istri \\ Utami $^{1}$ I Gusti Agung Sri Rwa Jayantini² I Wayan Budiarta ${ }^{3}$
}

\author{
${ }^{1}$ English Language Education Study Program, Universitas Pendidikan Ganesha, Singaraja, Indonesia \\ ${ }^{2}$ English Literature Education Study Program, Universitas Mahasaraswati, Denpasar, Indonesia \\ ${ }^{3}$ Linguistics Study Program, Universitas Warmadewa, Denpasar, Indonesia \\ *Corresponding author.Email: arie.suwastini@undiksha.ac.id
}

\begin{abstract}
As literature is argued to bring positive character values while being an entertaining medium for learning character education, the present study analyzed the five core values of character education in The Secret Life of Bees (2001). The study focused on the characterization of Lily Owens as the main character in representing good and evil characters in children. Descriptive qualitative was used to analyze the representation of character values using the Indonesian Ministry of Education and Culture's recommendation of five core values of character education as theoretical perspectives. The research revealed that Lily Owens' characterization represented all five core values recommended by the Ministry, although with different degrees of dynamics. Religious and independent values are presented as Lily's characters since the beginning of the novel, but nationalistic and cooperative value gradually developed along the conflicts that marks the raising actions of the plot. Integrity emerged late in the plot, yet it becale the key that unlock the mystery of Lily's mother. The completion of the five core values in Lily Owen's personality determined whether Lily Owens achieve the main goal at the climax of the plot. Thus, by reflecting on the core values exhibited through Lily Owens' character development, the novel illuminates how young adults can develop strong core values through life experience.
\end{abstract}

Keywords: Core values, Character education, Main character, Characterization.

\section{INTRODUCTION}

Virtues like wisdom, justice, fortitude, love, hard work, gratitude, self-control inspire people to do good [1], [2]. According to [3], virtue is the content of good character and the distinguishing mark of individuals, an essential aspect of one's life. Character is not only the prerequisite in facing the ever-growing challenges of the future. It also governs one's success. It determines whether one would be capable of becoming a lifelong learner with the necessary ability like the capable performer, skilled person, ethical thinker, democratic citizen, and self-disciplined person [4], [5]. Lickona [2] argues that character education is needed, especially when the worldwide phenomenon of character degradation is brought about by globalization and the democratization of technology faced by the $21^{\text {st }}$-century generation [5], [6].

However, character education is not the school's sole responsibility. Lickona in [2] states that good character should be modeled by school leaders, teachers, coaches, advisors, parents, and community members. Indonesian Ministry of Education and Culture [7] also emphasizes 
that character education is not limited to formal education. The Ministry further encourages innovative ways to develop students' characters through various media across formal, nonformal, and informal education, including digital media, movies, and literature. Literature like novels is interesting alternatives to introduce good values [8]-[15]. For younger children, literature can be read aloud by their parents or their teacher, providing stimuli that can instill good values among children [16]. Besides, popular literature like movies and games can also be fertile media for cultivating children's character [17]-[19].

The Secret Life of Bees is one of the famous novels written by Sue Monk Kidd, published in 2001 by Penguin Books. It was a New York Times bestseller and received the Best Books for Young Adult Award in 2003 and the Book of the Year Award in 2004 in addition to various critical acclaims

(https://www.ala.org/awardsgrants/content/ secret-lifebees-0). According to the official website of Sue Monk Kid, https://suemonkkidd.com/author/, the novel has been translated into 36 languages and sold more than eight million copies. The novel was adapted into a feature film by Disney in 2008, directed by Gina PrinceBythewood. Although the film adaptation will never be the same as the novel source [20], the adaptation process proves that The Secret Life of Bees has received good reception.

The novel is about a motherless-14 years-old adolescent named Lily who lived with an abusive father named T. Ray and a very kind peach picker named Rosaleen. Lily's life was not as beautiful as her name, as she lived with the memory of her mother's accident and her father's ignorance. Everything changed when Lily met the Boatwright sisters; August Boatwright, June Boatwright, and May Boatwright started her journey as a beekeeper and learned from the life of bees. Many have analyzed this novel, including [21] and [22]. The earlier revealed the symbolization of the female community through the image of the bees, and the latter focused on the main characters' motivation.

The profound moral values symbolized through the life of bees in Kidd's The Secret Life of Bees call for a further study of how the novel can be beneficial for young adults struggling for their identity, as undergone by the novel's main character, Lily Owens.

Using the recommendation of five core values by Indonesia's Ministry of Education and Culture, the present study aimed to elucidate the representation of the five core values in Lily Owens' characterizations. Such a study will illuminate how children can have specific values early on while seemingly confounding certain values. However, as suggested by [2], characters can be developed by enouncing the values in children's daily lives and their constant exposure to situations that strengthen them. Thus, the critical reading conducted in this study will identify the values represented in Lily Owen's characterizations while exposing the convoluted process of building characters among young adults.

\section{METHOD}

This study employed qualitative research from Miles et al. [23] to understand the social issues. The Secret Life of Bees was the research subject, while the research object was five core values proposed by the Indonesian Ministry of Education and Culture in 2017. In this design, the process of data collection and data analysis were conducted repeatedly, where the data analysis included the three concurrent processes of data condensation/data reduction, data display, and conclusion drawing. To collect the data, close reading was employed, supported by the segmentations of novel narratives into sequences and subsequences under the intention to make the units of analysis remain manageable [24]. The segmentation began with taking a significant event of the plot as a sequence. The sequences were then broken down into subsequences containing detailed incidents [25]. Actions, thoughts, behaviors, and interactions can reveal a character's traits [26]. During the data analysis, subsequences that include Lily Owen's actions, thoughts, behaviors, and interactions are scrutinized to identify the core values they represented. Elaboration of these core values was further developed during the data display to allow a comprehensive conclusion.

\section{RESULTS AND DISCUSSION}

As an adolescent girl growing up in a love-deprived environment, Lily Owens strived to maintain a need to study and aspire to be a professional writer. Her unhappy childhood with her ignorant and abusive father pushed her to leave home and arrive at the house of the Boatright sisters.

\subsection{Lily as a Religious Character}

Religious values are one of the essential values in Indonesia where it has to be understood and applied by society, a country whose foundation is the belief in God as signified through the first Sila in Pancasila. The religious values reflect faith in God, which manifest in applying religious norms, respecting other beliefs/religiosity, and living in peace among the difference in the society [7]. The religious values were identified in Lily's characterizations in at least 26 subsequences. However, the value is most vibrantly represented in $5 \mathrm{f}, 5 \mathrm{i}, 18 \mathrm{i}$, and $95 \mathrm{~h}$.

In subsequence $5 f$, Lily Lily was lying in her secret place, under the peach orchard where she buried her secret box that held her mother's belongings. She was examining the gloves that her mother once wore. Lily tried to feel her mother's warmth in the gloves, imagining how her touch would feel. At this moment, she felt a 
strong urge to find out how her mother had lived, to know her when she was alive. Later on, Lily's mind was fixated on this thought, so in subsequences 5i, Lily was described sneaking out to the orchard again, this time, observing another item from her mother's belonging, a honey bottle:

"The end-all mystery inside the bag was a small wooden picture of Mary, the mother of Jesus. I recognized her even though her skin was black, only a shade lighter than Rosaleen's."

(Kidd, 2001, p. 25-26).

The above excerpt shows that Lily's attention was fixated on the picture of Mary, the mother of Jesus. She examined the picture and found out the name of a place, "Tiburon." When Lily checked her map, she found out that it was a nearby town not more than two hours from Lily's hometown. With this information, Lily believed that she could go to Tibourne and find out why her mother had that honey bottle. Thus, the bottle with the picture of Black Mary had guided Lily to the right path to finding her mother's story. Through the picture of the Black Mary, God helped Lily because she had a strong and sincere desire to find out the mystery of the Black Mary and her mother's life. According to [27], religiosity refers to believing in God god and the power of relics and symbols as media for praying. Lily's belief in the power of the Black Mary to guide her. According to [28] and [29], believing in God's guidance to direct one's attitude is a reflection of the religious trait.

Lily's religious character continued to develop. In subsequence $18 \mathrm{i}$. Lily was really sad after she heard the truth about her mother from T. Ray. She was brokenhearted when T. Ray told her that her mother had left home without bringing Lily. When she returned to her bedroom, she found that the jar where she kept her bee pet was gone. Looking at the empty jar, it was described that Lily heard a mysterious voice:

I heard a voice say, Lily Melissa Owens, your jar is open. In a matter of seconds, I knew exactly what I had to do-leave

(Kidd, 2001, p.47-48).

There is a parallel between the bee and Lily, as they were both little, fragile, and stuck in a place where they did not belong. Thus, when the bee left the jar, Lily was moved to leave his father's house, seek her freedom, find her way of happiness and a lovely house. Bee is also a symbol of community which means the little bee would seek the queen bee, the mother of all bees. It also means that Lily would seek the truth of her mother in the search for a mother figure. The voice that Lily heard reflected her inner voice and guidance from a higher power for Lily to be brave and start her freedom journey. According to [30], a religious person believes in the power of God to guide her/him in making decisions. Thus, this inner voice can be interpreted as a message from God. Lily rested her life in the faith that she would be guided to the right place. Awareness of the spiritual dimension of the bee and mysterious voice as God's sign for the people [28], [31].

After a long journey from Sylvan to Tiburon and only bringing the picture of Black Mary, Lily and Rosaleen were led to the most eccentric house in Tiburon. It was painted bright pink, and there were beehives around the house. It was the house of the Boatwright sisters. August, June, and May Boatwrights were the bee farmers that produced the honey, which bottle Lily had kept as a memento of her mother. August Boatright openly welcomed Lily. June Boatright was initially skeptical of Lily because Lily had lied about why she came to their house. Living with the Boatright sisters, Lily learned about the prayers that the sisters did everything. They would sing the sacred song and touch the heart of Lady of Chains. It was hard for the first time for Lily, but when August told her about Lady of Chains, she felt moved:

This Mary I'm talking about sits in your heart all day long, saying, 'Lily, you are my everlasting home. Don't you ever be afraid. I am enough. We are enough.",

(Kidd, 2001, p 269).

The excerpt shows the meaning of Mary for the sisters. For the Boatright sisters and their friends, Lady of Chains was the miracle that saved their ancestor. Thus she was inside of everyone's heart and became a mother for everyone. Before this explanation, Lily hesitated in her belief about the Lady of the Chains. By now, Lily got a revelation, and she touched her heart, closing her eyes and absorbing every single of August's words. She realized that August was right, that Lily could feel the presence of Mary, the mother, in her heart. Lily realized that Mary would always be with her. The revelation that Lily had when touching the heart of the Lady of Chains represents that God is everywhere and also in our hearts, leading us to truth and happiness. By this sage of the plot development, the religious values have been firmly established in Lily's mind. Since then, Lily has regularly done praying, explicitly expressing her love to the Lady of the Chains as the representation of Mary, the Mother of Jesus. Praying is an action that represents religious values as an expression of gratitude to God [30], [32], [33].

The religious values are represented from the beginning until the end of the story, but they got stronger since Lily met August Boatwright. She attended worship and also heard stories about the survival of the Lady of the Chains. All the stories made Lily learn how to be a better person in life. Lily grew stronger beliefs in the power of God. In return, Lily felt she was stronger, loved, and more stable. 


\subsection{Lily as a Nationalist}

Nationalist is part of patriotic life. As a part of society in a country, nationalist values should be instilled in the people's hearts. In Indonesia, the nationalist and patriotic values are the third Sila in Pancasila. According to nationalism is about appreciating the national culture, being willing to sacrifice for the country, protecting the environment, respecting the different cultures, ethnicities, and religions, and loving the motherland. Nationalist value is also identified in Lily's characterizations in eleven subsequences. However, most substantial nationalist values appeared in subsequences $40 \mathrm{~d}, 75 \mathrm{~g}$, and $81 \mathrm{~g}$.

In subsequence 40d, Lily had a strong urge to tell her friends and teachers about their misconceptions about African-American people. As a white person growing up in South Carolina in the 1960s, Lily was educated to believe that white people were better than black people. As a white child, Lily was raised by T. Ray, who employed a lot of black peach pickers; one of them was Rosaleen, who ended up being Lily's sitter. However, after living with the Boatrights, Lily realized that the bad things said about the black people were not right. Thus, she wanted to set things right with her school:

Now I wished I could pen a letter to my school to be read at the opening assembly that would tell them how wrong we'd all been.

(Kidd, 2001, p 116).

The excerpt showed that Lily realized the equality of humans although they had different skin colors or ethnicity. After she met Zach, she realized that the African-American was the same as her. He was a human being, had changed for a better life, and tried making his dream come true. So she decided to send a letter to her old friends in Sylvan because she wanted them to open up their minds. Her story about Zach, Rosaleen, and Boatwright sisters would reconsider their segregated beliefs of race equality. This urge to write the letter and clarify can be read as a nationalist action because she intended to improve society by eliminating discrimination toward the African-American ethnicity. She respected the African-American ethnicity as equal to her Anglo-Saxon race. She also respected the black community's religion and their belief in the Lady of the Chains. Nationalist values are the attitude of loving the nation and having awareness as the part of society to support the nation and country, respecting the cultural and ethnic diversity of the country as equals [34]-[36].

Lily's nationalist character is also identified in sequence $75 \mathrm{~g}$, which is about the conversation between Lily and Zach in their free time about changing the world perception. Here is the excerpt of sequence $75 \mathrm{~g}$.

We can't think of changing our skin," he said. "Change the world."
(Kidd, 2001, p 204).

The setting of time in the novel was around the 1964s when racism toward African-Americans was rampant. From the conversation between Lily and Zach, they wanted to change the world's perception toward the African-America. Different ethnicities, cultures, habits, and beliefs were not accepted by the White, AngloSaxon, Protestant majority. The white people believed that African-Americans had a lower level than them, so they treated them differently. Many segregations mandated that different treatment should be given between African-Americans and the Anglo-Saxons, including the public sectors. For example, there were two kinds of hall rooms in the hospital: the colored section and the whites section. There were different seats for white and people of color. In the novel, Rosaleen gets arrested because she fought with a group of white people. She wanted to submit her petition about the black people's vote, which was achieved in the Southern United States like South Carolina in 1965. As the novel was set in 1964, the conversation between Lily and Zach above shows that Lily had a strong sense of nationalist value. They thought about changing the world's perception toward diversity, as they belonged to the same nation. This idealism is a reflection of nationalist value because they both wanted to unite the nation despite the racial, religious, and ethnic differences of the people in order to make a better country [5], [18], [36].

Subsequence $81 \mathrm{~g}$ revealed the extent of Lily's growing nationalist value. In this subsequence, she enthusiastically anticipated the elimination of the segregation law. Here is the excerpt in the novel related to the nationalist character.

Changes were coming, even to South Carolina-you could practically smell them in the air.

(Kidd, 2001, p 217).

The subsequence showed that Lily was daydreaming about the change in the world. She hoped one day there would be equality between whites and AfricanAmericans. She believed that when the world accepted them, they would have the same right as the whites. The term "smell them in the air" can mean that equality between whites and African-America was coming. According to [18] and [36], a nationalist thinks from the nation's perspective above the region's or personal perspectives. An individual's attitude to be more concerned about nation and country above the individual or group's interest makes a person a nationalist [37]. Thus, when Lily was expecting the changes coming to her country, she expressed a nationalist view. She started with a general scope covering the change, attaching her state, South Carolina, as part of the general scope: The United States of America. Nevertheless, by stating, 
"smell them in the air," Lily returned the scope to the broader extend, "the air" that can reach everywhere.

Thus, Lily's nationalist value in Monk Kidd's The Secret Life of Bees was shown to be developing. Raised with the privileges of white people around black people who worked for her father, Lily was educated with the prejudice that African-American people were the lowest class society. However, with the love from Rosaleen and the Boatright Sisters, Lily realized that she had prejudice inside her. Through daily interaction and conversation, Lily witnessed that African-American people were also intelligent and cultured like whites. The development of her nationalist value did not stop in herself. She also wanted to share the value with her teachers and her fellow students. She stood up for the sisters when T. Ray came and insulted the Boatright Sisters. Moreover, as a teenager inspired to be a writer, it could be expected that her writing would also spread the value more extensively.

\subsection{Lily as an Independent Girl}

Independence is one of the values that should be applied and taught from an early age. It reflects each individual's inner motivation and growth mindset to develop his/herself to be better for the sake of nation and country, inspiring the growth of the spirit of hardworking and equality as represented in the fifth Sila of Pancasila. According to [7], independence means the absence of dependence on other people's help for achieving her/his dream or hope. In Sue Monk Kidd's The Secret Life of Bees, this value is represented in at least forty-three subsequences. Three subsequences highlight the value most strongly, namely subsequences $2 \mathrm{~d}, 21$, and $58 \mathrm{~d}$.

In subsequence $2 \mathrm{~d}$, as an effort to find her mother, she traced the smell in her mother belongings:

I used to regularly go into the Sylvan Mercantile and smell every perfume bottle they had, trying to identify it.

(Kidd, 2001, p 17)

This part showed that Lily was trying to find out her mother's scent that she remembered. She went to the store by herself, trying to smell every perfume in the store to check the similarity between her mother's scent and the perfume in the store. Lily went there regularly, especially when the store had new products. This effort shows that she tried to solve the mystery of her mother's life and demise by herself. Lily independently tried to find a solution to her problem. Although finding the scent in the department store did not work, Lily solved the scent mystery when she recognized the smell in one of her teachers at school. Lily did it without the help of T. Ray because he was ignorant of Lily and would hate any conversation about Lily's mother. Thus, it would be impossible for Lily to get help from his father. So, he conducted her "research" to find her mother independently. It is in line with [13], [34], [38], that being independent is about not depending on others and using effort and critical thinking to accomplish the aims.

In subsequence 21, Lily's independent value was strongly represented in her effort to set Rosaleen free from the hospital. The following is an excerpt from subsequence 21 .

\section{A couple of minutes, trying to think up some kind of scheme.}

(Kidd, 2001, p 53).

The excerpt above shows how Lily tried to free Rosaleen from the hospital by thinking of "some kind of scheme.". She had to analyze the situation and condition to get out of the hospital without anyone noticing. First, Lily changed Rosaleen's appearance by changing her cloth and taking out the bandage on her head. Second, she tried to send the police guard back to the police station. She used the payphone in the hospital, acted as Ms. Gaston, and told him a lie to send him back to the police station. Third, Lily and Rosaleen had to act like hospital visitors to trick other people so that they could get out of the hospital. Those were Lily's ideas and tricks to set Rosaleen free from the hospital. She made those efforts for Rosaleen's sake and safety. She did not want Rosaleen to get hurt and suffer again. This series of efforts show her independence in finding every possible trick through analyzing the situation, finding related media or tools, and designing the schema of the plan. They also show how she thought critically in deciding the plan. Lily's persistence, critical thinking, and decisionmaking are independent values recommended by the Indonesian Ministry of Education and Culture [13], [39].

Lily's independence is also reflected in her plan for her future career. It is presented in subsequence $58 \mathrm{~d}$, as shown in the following excerpt.

I said to myself, Will wonders never cease? I would add that to my list of careers. A writer, an English teacher, and a beekeeper.

(Kidd, 2001, p 160).

The subsequence describes Lily's was wondering about being a beekeeper like August. She was also dreaming of being a writer and English teacher. Lily learned every day to make her dream come true. She learned about beekeeping by helping August and Zach with bees, beehives, and honey. For practicing her writing skills, Lily wrote something every day about anything when Lily had free time. Then she learned about English from school. It showed that Lily had the willingness to learn everything to accomplish her goals. Her motivation came from within, inspired by good models around her. She was not told and forced to do or be something. First, Lily was inspired by August, who was an independent, intelligent, and hardworking woman. Besides, she was amazed at the philosophy of 
bees every time she heard the story about bees from August. It made her want to be a beekeeper and add it to her bucket list. Second, she wanted to be a professional writer because she wanted to write every memory around her and make it immortal. Then Zach supported her inspiration by telling her about a professional writer and giving a notebook for Lily to make her write everything she liked. Third, she wanted to become an English teacher because she loved that subject in school. The teacher usually talked about literature or story which Lily loved. These internal motivations are another reflection of independent value. Independence is about believing in oneself to achieve anything that one is inspired to do [40]. The same persistence to achieve one's goal is also considered a representation of independent values by [13], [37].

\subsection{Lily as a Cooperative Individual}

Cooperative value is the foundation of Indonesia or the culture icon of Indonesia. From planning the decision, applying the decision until evaluating the decision. Cooperative also become the foundation of proposing Pancasila, in which all five Sila represent cooperative value to unite the different societies in Indonesia. According to the Ministry of Education and Culture in 2017 , cooperative is about working together with others to accomplish a specific purpose or solve a problem, establishing a spirit of togetherness and friendship, and helping each other. In Monk Kidd's The Secret Life of Bees, the value of cooperative became the central theme, symbolized through the life of the bees and the life of the women who worship the Lady of the Chains. However, from Lily Owen's characterizations alone, only nine subsequences were identified containing the representations of cooperative value. Among these subsequences, the value is most strongly identified subsequences 21a, 66a, and 41a.

In subsequence $21 \mathrm{a}$, Lily showed solidarity toward Rosaleen, who was hospitalized under police custody. She believed that she and Rosaleen should work together in escaping T. Ray and finding a better life. Here is an excerpt of sequence $21 \mathrm{a}$.

"I can't settle down till I know if she's all right," I said, my voice calmer but still shaking a little."

$$
\text { (Kidd, 2001, p 51). }
$$

This sequence is about Lily's effort to help Rosaleen go out of the hospital without getting caught. The above excerpt was Lily's answer when the police asked her not to worry about Rosaleen, presumably because Lily was white and Rosaleen was black. Her statement above reflected that she cared about Rosaleen, even though Rosaleen was black and only an employee to Lily's family. Nevertheless, Lily considered Rosaleen as a partner in surviving T. Ray. Thus, she devised a plan to free Rosaleen and executed it. First, Lily planned to send the police back to the police station. Then she continued with changing Rosaleen's appearance before acting like a visitor. Although most of the strategies were handled by Lily, Rosaleen also had an important part here. Rosaleen had to do the plan very well and tried to act as a visitor to avoid suspicion from others. With their collaboration, they could successfully get out of the hospital. On her first collaboration here, Lily and Rosaleen worked together to implement Lily's plan to set Rosaleen free from the hospital. Lily was trying to persuade Rosaleen to do the plan because she was unsure and afraid of Lily's plan. After Lily persuaded her, Rosaleen finally followed the plan, and they were successful. It showed how Lily and Rosaleen worked together for Rosaleen's sake. It was proof that Lily was a collaborative girl who helped others and worked together with others. Cooperative means doing something together to help others and make the work easier and faster [40]. Likewise, [39] and [41] also insist that cooperation is about friendship, where two or more people work together to achieve specific goals. Thus, Lily's help to free Rosaleen from the hospital represents a strong friendship between them, allowing them both to run away from the life they did not belong to.

In subsequence 66a, there was a collaboration between Lily, August, June, and Rosaleen to find May. Here is the excerpt of this sequence.

After twenty minutes she said, "That's it. Let's go get her. "Ma-a-a-a-y, " called August. June called, too, then Rosaleen and me.

(Kidd, 2001, p 181).

The excerpt is about the cooperation among Lily, Rosaleen, August, and June to find May, who was not back from the stone wall. Everyone was trying to find her by calling her name out loud and visiting several places that she usually visited. They tried so hard, scattering around the area and also calling the police. Then they found that May was floating on the river. It showed that they cooperated to find May. Meanwhile, it also showed that Lily did not feel ashamed of collaborating with African-Americans even though she was white. For Lily, Rosaleen, August, June, and May were her family, part of her life. She volunteered to do it for them, even when nobody forced her to help find May. She did it sincerely because of her love for May and others. Lily's effort to find May Boatright is another proof of Lily's cooperative value because the Indonesian Ministry of Education and Culture defines cooperative value as the spirit of togetherness and working together to help others [7]. Other researchers also identified collaboration in accomplishing a goal together as a reflection of cooperative value [41], [42].

Sequence 41a also Lily's cooperative attitude with Zach in working on bees in the honey house. Here is the excerpt of sequence $41 \mathrm{a}$. 
Every day Zach and I worked in the honey house.

(Kidd, The Secret Life of Bees, p 117).

The sequence shows that Lily and Zach were working together in the honey house. They did several things together, such as extracting the honey, harvesting the honey, changing the suppers, and watering the hives. Sometimes, Lily and Zach went to the town to sell the honey and the candles. This part also identified how Lily could collaborate with Zach to ease and speed up the work, so they could do other works or have more free time to rest and talk with others. Collaborative can increase togetherness, intimacy, and relationship. AS Lily and Zach work together more frequently, they build a strong emotional connection. While helping Zach with the bees, Lily learned bees' philosophy and became a better beekeeper, person, and woman. The bees inspired her to be a collaborative, hardworking, and helpful character. The Indonesian Ministry of Education and Culture [7] defines cooperative value as having the spirit of friendship and togetherness to achieve certain goals faster. Similar to Lily's and Zach's collaboration in subsequence 41a, [41], and [43] also identified doing several activities together as a representation of cooperative value.

\subsection{Lily and her Growing Integrity}

Integrity is one of the characters that is identified in the novel. Integrity value becomes an essential value that should be integrated into each individual. Integrity is about being trusted, responsible and patient, as represented in the fourth Sila of Pancasila. It helps the children become better individuals since they are the next generation who will develop Indonesia. According to the Ministry of Education and Culture [7], integrity is the value of being trusted in speech and action, being responsible with commitment, and being royal to humanity and moral values. In Monk Kidd's novel, Lily was presented to develop this value very gradually. As a teenager growing up in a dysfunctional home, Lily had to cheat her ways into studying and investigating her mother's life. Thus, she was conditioned to lie. In the novel, she was revealed to lie several times, although most of the dishonesty was justified by the reasons why she had to lie.

In subsequence $25 \mathrm{c}$, Lily was gaining information from the clerk in the restaurant by making an excuse about the clerk's question. Here is the excerpt.

$$
\begin{gathered}
\text { "I'm not from here. I'm visiting my } \\
\text { grandmother." }
\end{gathered}
$$$$
\text { (Kidd, The Secret Life of Bees, p 67) }
$$

This part showed that Lily lied about her purpose of visiting Tibourn to the clerk. Instead of stating her true purpose to find the honey maker, she lied that she had come to visit her grandmother. Lily chose to lie about the truth because she did not want the clerk to know about her identity. He might notice that Lily has run away from home. It can be said that Lily had lack of integrity at the beginning of the novel because she did not want to get into any trouble until she found out the truth about her mother. Despite the reason for the lie, not stating the trust is considered dishonesty [44].

Another dishonesty can be found in subsequence $27 \mathrm{f}$. In this subsequence, Lily and Rosaleen arrived at the Boatright's house. It is how she introduced herself and Rosaleen to August Boatright:

"Rosaleen...Smith, and Lily...Williams," I lied my mother died when I was little, and then my father died in a tractor accident.

(Kidd, The Secret Life of Bees, $\mathrm{p}$ 77)

In the excerpt, Lily lied about Rosaleen's family name, surname, and her father's whereabouts. Lily was lying about Rosaleen's identity because, at this point, Rosaleen was a fugitive running away from her jail time. She lied about her own identity because she was not sure. As a troubled young teenager, Lily was uncertain whether she would be accepted if she had told the truth. Lily had committed criminal offenses: she ran away from his father, busted Rosaleen out of police's detention, and stole at a supermarket. She lied about her family name and her father's status because she was an underage runaway. Any adult could contact Lily's father and send her home if they knew Lily's surname. Lily was afraid that August would be calling T. Ray to send her back to Sylvan and calling the police to arrest Rosaleen. Although she did that for her and Rosaleen's sake, telling a lie would be categorized as a liar or lack of integrity [44].

However, living with the Boatright sisters helped Lily develop a strong sense of integrity. After the first week of staying with the kind ladies, Lily's integrity was reflected in at least 23 subsequences. However, subsequences $84 \mathrm{f}, 85 \mathrm{a}$, and $88 \mathrm{a}$ represented her growing patience, honesty, and responsibility, which are the key traits that build integrity.

Subsequence $84 \mathrm{f}$ shows how Lily learned to be patient as she waited for the right time to tell her truth. It was stated that "I waited for August in her room" (Kidd, 2001, p 219). Lily had waited for a long time to talk about her feelings, the reason she came, the change she had been feeling. Before she decided to wait for August in her room to talk about everything, she had to wait because there had been numerous incidents in the family: Zach had an accident, May's fatal drowning, and the full preparation for the Mary Assumption Feast. Because everyone, including Lily, was very busy, Lily did not have time to be alone with August to have an intimate conversation. When her heart was ready, and she found the right time, she did not miss the time. Then Lily decided to wait for August in her room after the feast to 
talk about everything; about herself, Rosaleen, her mother, and father, how she ended up in Boatwright's house. Based on the explanation, Lily could control herself for waiting a long time, which is considered a reflection of patience by [45].

Lily's growing honesty is represented most strongly in subsequence $85 \mathrm{a}$. This sequence is part of Lily's true story as she told August Boatright. Even though Lily was afraid and wanted to run away from August's room, so she did not have to tell her story, she forced herself to stay and be honest with August. First, she admitted that her true name was Lily Melissa Owens and her mother was Deborah Fontanel Owens.:

"I laid out the photograph of my mother on the cedar chest.

$$
\text { “It's my mother," I said. }
$$

(Kidd, The Secret Life of Bees, p 221).

From the above excerpts, it can be seen that finally, Lily had the courage to reveal her identity. Lily went on to tell about the identity of her father:

"I glanced down at her hand still on mine, afraid she might move it. "I made that up," I said. "He's not really dead."

(Kidd, The Secret Life of Bees, p 223).

In the excerpt, Lily admitted that he had lied about his father's whereabouts. She also revealed the truth that his father was not dead. The other truth that Lily revealed to August was the reason why she had to hide Rosaleen's identity:

"The best I could, I told her the miserable details, careful not to leave anything out: Rosaleen practicing writing her name, the three men taunting her, how she poured snuff juice on their shoes."

(Kidd, The Secret Life of Bees, p 225).

This excerpt states that she is "careful nt to leave abything out" as her effort not to hide facts because, to be honest means telling the truth sincerely [35]. Thus, Lily told the truth about herself, Rosaleen's arrest, her father's cruelty, and her mother's deadly accident. She was very emotional while telling the truth because she felt sorry after lying to her on their first meeting. In the story, August Boatright told Lily that she knew Lily from the beginning. Augst knew Lily was lying, but she told Lily that she did not want to force Lily to tell the truth. As a reward for Lily's courage to tell her truth, August Boatright filled the blanks in Lily's story, solving Lily's quest to understand her mother's life and demise. It turned out, being honest helped Lily in finding answers to her questions. It also clears up Lily's misunderstanding about how August and June Boatright treated her because honesty prevents and solves the misunderstanding [46].

Subsequence $88 \mathrm{a}$ is an aftermath of Lily's emotional burst after hearing the story of her mother from August Boatright. Lily was stressed out and very sad after hearing the truth from August. She was trying to sleep, but she could not calm her emotion, and her tears did not stop wetting her face. She vented her anger by throwing the honey jar and messing up the honey house. Both the honey house and Lily were a mess. After the breakdown, she was calmer. Lily told Rosaleen about the truth while Rosaleen was tending Lily's injuries. After Lily was calm down, she realized the mess she had made, and she initiated the cleaning of the house. Here is the excerpt of sequence $88 \mathrm{a}$.

We wiped off the floors, and the walls then went
to work on Our Lady.

(Kidd, The Secret Life of Bees, p 247).

Lily's action in cleaning the mess that she had created reflects a sense of responsibility-being responsible means being committed to one's obligation to ensure that everything runs smoothly [7]. According to [37], handling the effect or consequences of pone's action represents responsible value. Thus, Lily's willingness to clean up the mess she caused even when nobody forced her to clean up was an act of responsibility.

Thus, Lily's integrity was built during her stay with the Boatright sisters. She was mischievous and deceitful at the beginning of the story because she lacked affection from her dad. No affection means no attention, no knowledge of right and wrong, and no good communication. It would make the children do anything that they thought was right. After her long journey to Tiburon and living with the Boatwright family, Lily's life changed. She got many affections from August, June, May, and Rosaleen. They taught Lily how to be patient and honest when taking care of the bees. Every step of the bee's production into honey made Lily learn about being patient. Every process was meaningful, and the process will be rewarded with honey. Lily's development of integrity shows that it is essential to give children a good model of integrity because they copy the adults around them. Children will be liars when children grow up with laying adults like how T. Ray often lied to Lily. Children cheat their ways when they are prohibited from being creative, like how T. Ray forbade Lily to study or clean herself. Lily's growing integrity after living with the Boatright's also sends a message that it is not too late to educate children who had the wrong upbringing.

\section{CONCLUSION}

The present study revealed that Sue Mon Kidd's award-winning novel, The Secret Life of Bees, presents its main character with a dynamic characterization that 
reflects the formation of character values. Guided by The Indonesian Ministry of Education and Culture's recommendation of the five core values, the present study identified religious and independent as Lily's most substantial values since her characterizations represent these values early from the beginning of the plot. The development of nationalistic and cooperative values happened medias-res when conflicts started to bring Lily Owens and Rosaleen to run away together. These values continued to grow as Lily met more people. Integrity was the value that Lily had to cultivate because her upbringing did not support introducing this value. Only when she lived with the Boatright sisters did she start fostering this value, delivering her to a bigger truth about her mother and life.

Thus, the novel provides clues to how characters can be cultivated through education and good models around the children. Good values develop through habituation and simultaneous implementation. Society, parents, and teachers play critical roles in providing models and experiences that condition the growth of moral values. Hence, the present study suggests that stakeholders design more effective curricula that integrate character education values into formal education both inside and outside the classrooms. Moreover, it also suggests that teachers, future teachers, and parents are readers to constantly provide good models of core values to children around them while guiding them to implement those values in their behaviors and actions continuously.

\section{REFERENCES}

[1] R. Hursthouse and G. Pettigrove, "Virtue Ethics," The Stanford Encyclopedia of Philosophy, 2018. https://plato.stanford.edu/archives/win2018/entri es/ethics-virtue/.

[2] T. Lickona, Character Matters: How to Help Our Children Develop Good Judgement, Integrity and Other Essential Virtues. New York: Simon and Schuster, 2004.

[3] T. Lickona and T. Roosevelt, "The Return of Character Education," Educ. Leadersh., vol. 51, no. 3, pp. 6-11, 1993, [Online]. Available: https://eric.ed.gov/?id=EJ472598.

[4] J. V. Hutapea and N. K. A. Suwastini, "Using short films for teaching English while building characters," Ling. Sci., vol. 26, no. 1, pp. 33-37, 2019, doi: 10.23887/ls.v26i1.18846.

[5] I. G. A. L. P. Utami, N. K. A. Suwastini, N. N. Artini, and U. Kultsum, "Values of character education in the characterizations of Dory in Disneys' animated feature Finding Dory (2016)," Int. Conf. Innov. Res. Across Discip. (ICIRAD 2019), vol. 394, no. ICIRAD 2019, pp. 119-126, 2020, doi: 10.2991/assehr.k.200115.020.

[6] N. K. A. Suwastini, G. R. Dantes, I. N. L. Jayanta, and C. T. Suprihatin, "Developing Storyline for Role-Playing Games Based on Balinese Folklore for Preserving Local Wisdom and Character Education," vol. 394, no. Icirad 2019, pp. 361-366, 2020, doi: 10.2991/assehr.k.200115.059.

[7] Kemendikbud, "Gerakan Penguatan Pendidikan Karakter (PPK) [Infographics of the Strengthening Character Education Movement]," Indones. Minist. Educ. Cult., pp. 1-10, 2017, [Online]. Available: cerdasberkarakter.kemendikbud.go.id.

[8] A. Himmah and E. N. Sa'adiyah, "Moral values in 'The Hunger Games' novel to build students' character," J. al-Hikmah, vol. 5, no. 1, pp. 54-61, 2017, [Online]. Available: https://jurnal.staiba.ac.id/index.php/Al-

Hikmah/article/view/39/37.

[9] A. Ralia, Kasmaini, and Indah, "A Description of Moral Values in JK Rowling's Novel," J. Bhs. Inst. Agama Islam Negeri Bengkulu, vol. 88, no. 1, pp. 50-58, 2019, doi: http://dx.doi.org/10.29300/lughah.v8i1.2349.

[10] L. Riskayani, N. K. A. Suwastini, and L. G. E. Wahyuni, "Gender issues in Mary Norton's novel entitled 'The Borrowers': A library research," SPHOTA J. Linguist. dan Sastra, vol. 13, no. 2, pp. 1-10, 2021, doi: 10.36733/sphota.v13i2.2103.

[11] G. A. M. R. Suarniti, "Values of Life in Mitch Albom's 'Tuesday With Morrie," RETORIKA J. Ilmu Bhs., vol. 5, no. 2, pp. 91-96, 2019, doi: 10.22225/jr.5.2.1096.91-96.

[12] N. K. A. Suwastini, N. W. D. P. Asri, L. G. E. Wahyuni, and K. A. D. Prastika, "the Characterisations of Piscine Molitor Patel in Yan Martell'S the Life of Pi," Int. J. Lang. Lit., vol. 4, no. 2, p. 56, 2020, doi: 10.23887/ijll.v4i2.30289.

[13] N. K. A. Suwastini, I. D. A. O. V. J. Banjar, L. P. C. A. Tienty, I. M. D. G. Sasmita, and P. K. Nitiasih, "Rachel Chu as liberal feminist in Kevin Kwan's Crazy Rich Asians (2013)," Int. J. Lang. Lit., vol. 4, no. 3, pp. 123-132, 2020.

[14] N. K. A. Suwastini, G. A. P. Suprianti, and N. T. Suparyanta, "Demystification of the Myth of Freedom in the Characterization of Christopher McCandless in Krakauer's Into The Wild," NOBEL J. Lit. Lang. Teach., vol. 10, no. 1, pp. 1-14, 2019, doi: https://doi.org/10.15642/NOBEL.2019.10.1.0114.

[15] N. W. D. Widasuari, N. K. A. Suwastini, L. G. E. Wahyuni, and N. P. A. Visestayati, "Lucy Pevensie'S Characterizations in C.S. Lewis' Narnia: the Lion, the Witch, and the Wardrobe," Int. J. Lang. Lit., vol. 4, no. 1, p. 47, 2020, doi: 10.23887/ijll.v4i1.30227.

[16] J. Senawati, N. K. A. Suwastini, I. G. A. S. R. Jayantini, N. L. P. S. Adnyani, and N. N. Artini, "The Benefits of Reading Aloud for Children: A Review in EFL Context," IJEE (Indonesian J. English Educ., vol. 8, no. 1, pp. 73-100, 2021, doi: https://doi.org/10.15408/ijee.v1i1.19880. 
[17] N. K. A. Suwastini, W. Lasmawan, N. N. Artini, and N. W. S. Mahayanti, "Mixed messages about environmental awareness in Disney's 2016 Finding Dory," Asian EFL J., vol. 27, no. 4.1, pp. 73-93, 2020, [Online]. Available: https://www.asian-efl-journal.com/wpcontent/uploads/AEJ-Volume-27-Issue-4.1October-2020.pdf.

[18] N. K. A. Suwastini, I. W. Swandana, and N. L. P. D. Payani, "The identification of character education values on the main character of Zootopia," J. Pendidik. Bhs. Ingg. undiksha, vol. 5, no. 2, 2018.

[19] N. K. A. Suwastini, I. A. I. Utami, and E. W. Galla, "The popular and the academic: performing analysis on Disney's Beauty and the Beast (2017)," in Fourth International Conference on English Across Culture, 2018, no. 4, pp. 47-57.

[20] N. K. A. Suwastini, "In/fidelity Criticism: Menuju Kajian Adaptasi yang Lebih Kritis dan Terbuka," 2014, [Online]. Available: http://digilib.mercubuana.ac.id/manager/t!@file artikel_abstrak/Isi_Artikel_757195382109.pdf.

[21] J. Rajendran, "An affirmation of Black Culture through revolution of signs: A new historicism insight into Sue Mon Kidd's The Secret Life of Bees," Sch. Int. J. Multidiscip. Allied Stud. ISSN 2394-336X, vol. 5, no. 9, p. 99, 2018, doi: 10.19085/journal.sijmas050901.

[22] N. Saidah, D. Sunggingwati, and C. Asanti, "Motivation of the main character in Sue Monk Kidd's Secret Life of Bees," J. Ilmu Budaya, vol. 3, no. 1, pp. 99-105, 2019, [Online]. Available: http://e-

journals.unmul.ac.id/index.php/JBSSB/article/vi ew/1628/pdf.

[23] M. B. Miles, A. M. Huberman, and J. Saldana, Qualitative data analysis: A methods sourcebook, 3rd ed. California: SAGE Publications, 2014.

[24] D. Bordwell and K. Thompson, Film Art Introduction, 8th ed. QUebec: The McGraw Hill Companies, 2008.

[25] N. K. K. Dewi, N. K. A. Suwastini, and I. G. A. S. R. Jayantini, "The Characterization of Amanda Collier in Nicholas Sparks' The Best of Me (2011)," Int. J. Lang. Lit., vol. 5, no. 3, pp. 123-136, 2021, [Online]. Available: https://ejournal.undiksha.ac.id/index.php/IJLL/a rticle/view/34934/19961.

[26] R. Gill, Mastering English Literature, Second Edi. Hampshire: Palgrave, 1995.

[27] K. Engebretson, Catholic schools and the future of the church. Bloomsbury Publishing, 2015.

[28] O. A. Putriyanti, R. Winarni, and M. Rohmadi, "Religious education values in Gita Savitri Devi's Rentang Kasih and Andori Andriani's Doriyaki Novels," Budapest Int. Res. Critics Linguist. Educ. J., vol. 2, no. 4, pp. 560-565,
2019, doi: 10.33258/birle.v2i4.550.

[29] Darmayenti, Besral, and L. S. Yustina, "Developing EFL religious characters and local wisdom based EFL textbook for Islamic higher education," Stud. English Lang. Educ., vol. 8, no. 1 pp. 157-180, 2021, doi: 10.24815/siele.v8i1.18263.

[30] N. C. Mugrib and Z. Zulfah, "Pilar's existence in her love story shown in Paulo Coelho's By The River Piedra I Sat Down and Wept," NOBEL J. Lit. Lang. Teach., vol. 7, no. 2, pp. 98-119, 2016, doi: 10.15642/nobel.2016.7.2.98-119.

[31] E. D. Hutubessy, "The building of main character's self-actualization through religion in Hermann Hesse's Siddhartha," NOBEL J. Lit. Lang. Teach., vol. 10, no. 2, pp. 174-184, 2019, doi: 10.15642/nobel.2019.10.2.163-173.

[32] D. Z. Jauhara, E. S. Setianingsih, and M. A. K. Basyar, "Analyzing the religious values in a novel entitled Hafalan Shalat Delisa by Tere Liye," PAJAR (Pendidikan dan Pengajaran), vol. 5, no. 4, pp. 1043-1064, 2021, doi: http://dx.doi.org/10.33578/pjr.v5i4.8173.

[33] D. A. Ikawati, "Analysis of the Characters of Interview With the Vampire, a Novel By Anne," Ling. J. Lang. Lit. Teach., vol. 13, no. 1, p. 143, 2016, doi: 10.30957/lingua.v13i1.22.

[34] N. Listiawati, "The implementation of the strengthening character education in sdn 09 mataram city, nusa tenggara barat," J. Pendidik. Karakter, vol. 8, no. 1, pp. 17-28, 2018, doi: 10.21831/jpk.v8i1.21668.

[35] A. A. Kusumawati, "Pendidikan karakter bangsa dalam puisi 'Malu (Aku) Jadi Orang Indonesia' karya Taufiq Ismail," Adab. J. Bhs. dan Sastra, vol. 12, no. 2, p. 332, 2013, doi: 10.14421/ajbs.2013.12206.

[36] E. Ismawati, "Nationalism in Indonesian literature as active learning material," Int. J. Act. Learn., vol. 3, no. 1, pp. 33-48, 2018.

[37] M. R. Abdulfatah, S. T. Widodo, and M. Rohmadi, "Pendidikan karakter dalam novel Maha Mimpi Anak Negeri karya Suyatna Pamungkas: Tinjauan psikologi sastra," $J$. Gramatika, vol. 1, pp. 12-23, 2018.

[38] Suwarno, K. Saddhono, and N. E. Wardani, "Structural Analysis And Character Value In The Kijang Masinan Legend Ngrayudan Ngawi," $J$. Pendidik. Bhs. dan Sastra Indones., vol. 4, no. i2, pp. 365-375, 2018.

[39] D. Hadiansah, H. Sari, and E. Sugianto, "The values of character education in the novel of Dilan 1990 written by Pidi Baiq: Sociology study," Ethical Ling. J. ..., vol. 8, no. 1, pp. 313320, 2021, [Online]. Available: https://www.ethicallingua.org/25409190/article/ view/286.

[40] B. D. Regina and A. R. Wijayaningputri, "Analysis of Parang Mask Batik Character Education as a aorm of character building for 
elementary school children," J. Teach. Learn. Elem. Educ., vol. 3, no. 2, p. 142, 2020, doi: 10.33578/jtlee.v3i2.7852.

[41] D. M. Idris and M. K. Zubair, "Religious meaning in social practices: A study of Muslims tolerant attitudes in South Sulawesi," Indones. J. Islam. Lit. Muslim Soc., vol. 4, no. 1, p. 1, 2019, doi: 10.22515/islimus.v4i1.1702.

[42] E. Riyaningsih, Maryono, and Harini, “Establishment of Learners' Character Through Learning Traditional Dance in Senior High School," Harmon. J. Arts Res. Educ., vol. 18, no. 1, pp. 13-27, 2018, doi: 10.15294/harmonia.v18i1.12575.

[43] K. Sujatmoko and N. Ayuningtias, "The values of local wisdom in Dedeng: A vocal tradition of Malay Langkat community," J. Polingua Sci. J. Linguist. Lit. Educ., vol. 6, no. 2, pp. 24-32, 2016, doi: 10.30630/polingua.v6i2.83.

[44] N. Nikita, R. Andela, G. Z. Fauziah, and Z. A. Nazafi, "The contrast portrayals of American and Pakistani culture in The Big Sick movie," Insa. J. Islam Humanit., vol. 3, no. 2, pp. 111-126, 2019, doi: https://doi.org/10.15408/insaniyat.v3i2.11124.

[45] B. Dann, Better Children Sermons: 54 Visual Lessons, Dialogues, and Demonstrations. United States of America: Westminster John Knox Press, 1983.

[46] T. N. Fitria, "An Analysis of Moral Values Found in a Korean TV Series, The World of Married '," no. 2008, pp. 52-64, 2020. 